\title{
“O PRIMADO DA TOTALIDADE" EM LUKÁCS: UM DEBATE À LUZ DA HERANÇA MARXIANO-HEGELIANA
}

\author{
Antonio Marcondes dos Santos Pereira ${ }^{1}$ \\ Bruno Alysson Soares Rodrigues ${ }^{2}$ \\ Eduardo Ferreira Chagas ${ }^{3}$
}

\begin{abstract}
Resumo
Nosso objetivo no presente artigo é analisar como a categoria da totalidade é compreendida por Lukács à luz da influência de Hegel e Marx, bem como, as controvérsias suscitadas no âmbito da tradição do pensamento marxista. Como um legatário da tradição "marxiano-hegeliana", Lukács sempre reclamou "o primado da totalidade" sobre as partes que a compõem. Em História e consciência de classe, o filósofo húngaro critica o mundo reificado da sociedade capitalista e sua fragmentação, nesse sentido, enxerga na consciência do proletariado a possibilidade concreta de um conhecimento que apreenda a totalidade da vida social, entretanto, essa interpretação foi fortemente marcada pela influência hegeliana, o que significa que é a subjetividade, a consciência, o pensamento lógico que prevalece na análise crítica do real. Já na sua Ontologia do ser social, de influência decididamente marxiana, a preponderância do fator ontológico da realidade na fundamentação do método dialético é o que confere às suas interpretações um caráter radicalmente histórico-concreto, ou seja, o ponto de partida é a realidade objetiva.
\end{abstract}

Palavras-chave: Totalidade. Dialética. Pensamento. Realidade. Tradição marxiano-hegeliana.

\section{"THE PRIMACY OF TOTALITY" IN LUKÁCS: A DEBATE IN THE LIGHT OF THE MARXIAN-HEGELIAN HERITAGE}

\begin{abstract}
Our purpose in this paper is clearly understand how the category of totality is understood by Lukács according by the influence of Hegel and Marx, as well as the controversies raised within the tradition of Marxist thought. As a "Marxian-Hegelian" tradition legatee, he has always claimed "the primacy of wholeness" over its component parts. In his work History and class consciousness, Lukács criticizes the reified world of capitalist society and its fragmentation, in this sense, he sees in the proletariat consciousness a concrete possibility to build a knowledge that apprehends the totality of social life, however, this interpretation was strongly marked by the hegelian
\end{abstract}

1 Graduado em História pela Universidade Estadual do Ceará (UECE/Campus FECLESC-Quixadá). Mestre em Educação pela UECE. Doutor em Educação Brasileira pela Universidade Federal do Ceará (UFC) na linha: Filosofia e Sociologia da Educação (FILOS), Pós-Doutorando em Educação pelo PPGEB-UFC e membro do Grupo de Estudos Marxistas da UFC (GEM) e do Grupo de Pesquisa Ontologia do Ser Social, História, Educação e Emancipação Humana - GPOSSHE (UECE). ORCID: https://orcid.org/0000-0002-0890-9011. Email: antonio.marcondes@uece.br.

2 Graduado em Pedagogia pela Universidade Estadual do Ceará (UECE/Campus CED-Itaperi). Mestre em Educação pela UECE. Doutorando em Educação pelo Programa de Pós-Graduação em Educação da UECE na linha A: Formação, Didática e Trabalho Docente, Núcleo 4: Educação Escolar, Formação, Luta de Classes e Pedagogia Histórico Crítica. Membro do Grupo de Pesquisa Ontologia do Ser Social, História, Educação e Emancipação Humana - GPOSSHE (UECE). ORCID: https://orcid.org/0000-0003-1798-8177. E-mail: bruno.alysson@aluno.uece.br.

3 Pós-Doutorado em filosofia pela Universidade de Münster, Alemanha, Doutor em Filosofia pela Universität von Kassel (KASSEL, ALEMANHA, 2002). É professor efetivo (associado) do Curso de Filosofia e do Programa de Pós-graduação em Filosofia da Universidade Federal do Ceará (UFC) e professor colaborador do Programa de Pós-graduação em Educação Brasileira da Faculdade de Educação (FACED/UFC). Coordenador do Grupe de Estudos Marxistas (GEM), do eixo de pesquisa Marxismo, Teoria Crítica e Filosofia da Educação. Orientador do Programa Jovens Talentos/CNPq. Atualmente é Pesquisador Bolsista de Produtividade do CNPq; é membro da Internationale Gesellschaft der Feuerbach-Forscher (Sociedade Internacional Feuerbach) e dedica suas pesquisas ao estudo da filosofia política, da filosofia de Hegel, do idealismo alemão e de seus críticos Feuerbach, Marx, Adorno e Habermas. Editor-chefe da Revista Dialectus (UFC). ORCID: https://orcid.org/0000-0003-1957-6117. E-mail: ef.chagasbol.com.br. 
influence, which means that the subjectivity, the conscience and the logical thought is that prevails in the critical analysis of the real. In his Ontology of the social being, with a decidedly marxian influence, the ontological factor preponderance on reality in the process of dialectic method foundation is what gives his interpretations a radically historical-concrete character, that is, the starting point is reality.

Keywords: Totality. Dialectic. Thought. Reality. Marxian-Hegelian tradition.

O "primado" do todo sobre as partes que o conformam, é o postulado central do pensamento dialético. Em Hegel, por exemplo, é a ideia do "todo" que constitui a "verdade", que se expressa pela contraditoriedade histórica da realidade. Nesse sentido, a contradição inerente à realidade faz com que esta não se turve com os seus variegados momentos constitutivos. Desde Heráclito, a dialética reclama a primazia ontológica do universal, da totalidade, enquanto um apanágio da realidade; "uma realidade mais real" do que as partes que a constituem (FREDERICO, 2013).

Assim, Celso Frederico explica a diferença entre a totalidade em Hegel e em Marx:

Em Hegel, há a ideia de uma totalidade prévia, que se fragmenta pelas sucessivas alienações. No final da caminhada, o Espírito Absoluto tudo concilia numa totalidade harmoniosa, em que as partes enfim se reconhecem em sua racionalidade como pertencentes ao todo. Mas a escrita de Hegel não é transparente: nunca se sabe ao certo se para ele as categorias derivam do pensamento ou da realidade. Às vezes ele é idealista, outras vezes se aproxima do materialismo (FREDERICO, 2013, p. 97).

Já em Marx:

[...] o lugar das peripécias do Espírito é ocupado pela saga da vida social dos homens. Desprendendo-se da natureza pelo trabalho, fazendo dela o seu objeto, o homem tornou-se um ser vivo. O mundo social - o objeto - não é algo totalmente estranho, mas um produto da atividade humana. Com isso, rompe-se com o dualismo e reafirmase a visão monista, o primado da totalidade (FREDERICO, 2013, p. 97).

O recurso à categoria da totalidade aparece em vários momentos na obra de $\mathrm{Marx}^{4}$.

E aqui ao tratarmos do método dialético, ela se expressa exatamente quando Marx entende que a sociedade capitalista é uma totalidade socialmente articulada e constituída. O pensamento de Marx exige a reconstrução conceitual do todo, pois "a sociedade não é uma colcha de retalhos", mas, sim, "uma totalidade viva e articulada". Um exemplo disso, "é aquela passagem em que

4 Em sua Contribuição à crítica da economia política, por exemplo, Marx afirma que: "Para a consciência - e a consciência filosófica é determinada de tal modo que para ela o pensamento que concebe é o homem real, e o mundo concebido é, como tal, o único mundo real - para a consciência, pois, o movimento das categorias aparece como o verdadeiro ato de produção - que apenas recebe um impulso do exterior - cujo resultado é o mundo, e isso é exato porque [...] a totalidade concreta, como totalidade de pensamento, como uma concreção de pensamento, é, na realidade, um produto do pensar, do conceber; não é de nenhum modo o produto do conceito que se engendra a si mesmo e que concebe separadamente e acima da intuição e da representação em conceitos. O todo, tal como aparece no cérebro, como um todo mental, é um produto do cérebro pensante, que se apropria do mundo da única maneira em que o pode fazer, maneira que difere do modo artístico, religioso e prático de se apropriar dele [...]" (MARX, 2008, p. 259-260, itálico nosso).

\begin{tabular}{|l|l|l|l|l|}
\hline Q & Disita \\
\hline
\end{tabular}


Marx disse que a superestrutura não tem História, isto é, que ela não possui uma história própria, movida por leis próprias, apartadas e deslocadas, do processo de constitutividade da sociabilidade humana. Assim, não haveria [...] uma história da literatura, do cinema [...] A arte não se desenvolve sozinha", mas, ao contrário, ela, a história, "expressa o movimento geral da sociedade", expressa a devida articulação entre as partes que compõem o todo. Portanto, as grandes escolas ou tendências literárias, "se sucederam", no tempo, "como um reflexo das grandes transformações ocorridas na vida social", e, não por um processo de desenvolvimento independente da própria literatura (FREDERICO, 2013, p. 97-98, itálico no original).

Em Lukács, também, a totalidade é uma categoria presente em muitas de suas obras. Como um legatário da tradição "marxiano-hegeliana", sempre reclamou "o primado da totalidade" sobre as partes que a compõem. Em História e consciência de classe, Lukács critica o mundo reificado da sociedade capitalista e sua fragmentação que também se expressará no pensamento, nesse sentido, enxerga na consciência do proletariado, e não na constitutividade contraditória da totalidade em que esta classe está inserida, a possibilidade concreta de um conhecimento que apreenda a totalidade da vida social. Quando, no momento revolucionário, sujeito e objeto, que estavam cindidos, se "reconciliam" e, por conseguinte, se "identificam", a totalidade, portanto, é reconstituída na consciência do proletariado, mas não por um processo de apreensão da contraditoriedade dos processos históricos envolvidos, mas sim por um movimento subjetivo de encaixe desta consciência dita revolucionária no momento histórico vivido.

Também na crítica literária de Lukács o tema da totalidade é apresentado reiteradamente. E nessa perspectiva:

Não é mais a consciência do proletariado, mas o olhar do romancista que pode reproduzir o mundo como uma totalidade fechada. O romance, assim, vence a impressão fantasmagórica de uma realidade mecânica ao nos apresentar, numa totalidade complexa, o livre curso do desenvolvimento dos destinos humanos. $\mathrm{O}$ romance como gênero literário é a expressão artística mais acabada do mundo burguês [...] (FREDERICO, 2013, p. 98).

Pois, o propósito que Lukács (2011, p. 28-29) pretendia atingir com essa nova perspectiva (como ele afirma em nota à edição alemã do seu livro $O$ romance histórico originalmente publicado em 1936-7), era realizar "uma investigação da interação entre espírito histórico e a grande literatura que retrata a totalidade da história, e isso apenas em relação à literatura burguesa [...]". Esse ideal manifesto de Lukács em combinar a "elaboração total" do ponto de vista da história com "o tratamento exaustivo da totalidade do desenvolvimento histórico", portanto, visava tornar "apreensível a todos a verdadeira força da dialética marxista".

\begin{tabular}{|l|l|l|l|l|}
\hline Qovista Dialectus & Ano 10 & n. 21 & Janeiro - Abril 2021 & p. 340 - 369 \\
\hline
\end{tabular}


Desse modo, segundo Celso Frederico (2013, p. 99, aspas do original):

Perante os novos desafios, a burguesia torna-se uma classe conservadora, interessada apenas em manter a ordem social. A sociedade não é mais o palco da história social, dos conflitos e da busca do conhecimento da verdade. Agora, ela passa a ser vista como uma segunda natureza, e o pensamento faz a apologia do existente. A democracia é substituída pelo liberalismo [...] nesse momento, o romance sofre uma alteração [...] O Realismo clássico, sem ter mais as condições sociais que propiciaram sua afirmação como gênero, cede lugar ao Naturalismo, com dois representantes máximos: Flaubert [...] e Zola [...] O romance, entendido como um resgate da totalidade perdida, entra numa fase aguda de crise. Lukács ressalta o papel criador de Thomas Mann e Malraux e deposita esperanças nas possibilidades artísticas do "socialismo real". Mas, afora essas e outras raras exceções, passou a ver em toda parte a expressão da decadência ideológica da burguesia [...]

$\mathrm{O}$ romancista enquanto um autor que reflete a realidade em sua natureza essencial, a partir da perspectiva da totalidade, consegue desvelar o em-si da realidade ofuscada ou dissimulada pela ideologia burguesa que se expressa pelo viés da política, da arte, da cultura e das ideias de um modo geral, conforme pensa o Lukács. Por isso, o Realismo reivindicado por Lukács consiste em um "procedimento estético" ancorado em dois eixos fundamentais: o auxílio à "tipicidade" e o "método narrativo"6. Para Lukács, a arte tem a função de refletir a natureza essencial da realidade social, "o mundo dos homens", enquanto uma totalidade historicamente articulada pela relação dialética entre essência e a aparência. Isso leva "o verdadeiro artista a desmascarar a impressão fantasmagórica, a aparência enquanto aparência, enquanto dissimulação da essência" (FREDERICO, 2013, p. 91).

A verdadeira arte, portanto, engendra uma ruptura no processo de fetichização social em virtude do seu "caráter humanizador". Isto porque, ao refletir sensitivamente "o destino dos homens", o escritor (romancista) coloca em foco a "condição humana" no contexto dos processos sociais que obstaculizam as suas possibilidades de desenvolvimento. Com esse

5 O realismo implica, a meu ver, a fiel reprodução de personagens típicos em situações típicas'. Essa definição, formulada por Engels numa carta à escritora inglesa Margareth Harknes foi desenvolvida amplamente por Lukács [...] Para o pensamento dialético, o tipo não de vê ser uma construção intelectual apriorística e abstrata, feita à revelia da realidade e privilegiando o sujeito cognoscente (como quer Weber), e nem uma construção estatística que abstrai a riqueza e a diversidade presentes na realidade, como é o 'tipo médio' durkheiminiano [...] A questão, evidentemente, pressupõe outra: saber o que os diversos escritores entendem por realidade e, consequentemente, a maneira como procuram reproduzi-la artisticamente. (FREDERICO apud ENGELS, 2013, p. 105-107, itálico no original)

6 A ênfase na narração como característica básica do Realismo apoia-se em três pontos: 1) na ideia hegeliana de que o traço essencial da epopeia é o relato dos fatos passado. Nessa ótica, o romance é entendido como 'a epopeia do mundo burguês'. É este distanciamento temporal que permite ao autor separar o essencial do acidental no acompanhamento dos 'destinos humanos' [...] 2) [...] a figuração dos 'destinos humanos', trazida para o primeiro plano, revela a postura humanista de Lukács e o critério que sempre lhe servirá como referencial para julgar as obras literárias [...] e 3) [...] finalmente, o método narrativo tem como principal modelo o romance realista do século XIX, termo de comparação recorrente em toda a crítica literária de Lukács [...] Com tais referências, Lukács define o romance como um processo, um 'curso' que exige o método narrativo para se reproduzir com fidelidade os 'destinos humano. (FREDERICO, 2013, p. 109, itálico no original)

\begin{tabular}{|l|l|l|l|l|}
\hline Q & Ano 10 & n. 21 & Janeiro - Abril 2021 & p. 340 - 369 \\
\hline
\end{tabular}


fito, o romancista toma posição, e passa a defender de forma apaixonada a humanidade "ameaçada pelas formas desumanizadoras de opressão", diz Celso Frederico. Portanto, para Lukács, o Realismo constitui um método, o caminho correto para representar de forma artística a realidade humana e, como critério para aferir as produções estéticas.

Retomando as questões referentes à passagem da categoria da totalidade em História e consciência de classe para a Ontologia, podemos entender que essas referências que Lukács faz à totalidade demonstram o quanto essa categoria tem fundamental relevância, além de ser decisiva na fundamentação do método dialético marxista. A apresentação das ideias mestras de Lukács que viriam a ser a base da Ontologia ocorreu numa conferência ministrada pelo filósofo húngaro em 1968, conhecida como As bases ontológicas da atividade humana. No entanto, Lukács não chegou a concluir como desejava sua última grande obra, havia ficado insatisfeito com a forma de exposição, que considerava insuficiente. Na primeira parte da obra, Lukács discute problemas do conhecimento a partir de autores como Carnap, Wittgenstein, Nicolai Hartmann, Hegel e Marx. Já na segunda parte, trata de questões relacionadas aos complexos categoriais decisivos do ser social: o trabalho, a reprodução social, momento ideal ou ideologia e o estranhamento.

Os originais da Ontologia foram discutidos com os seus discípulos da chamada “Escola de Budapeste”. Eram eles: Agnes Heller, György Markus, Ferenc Fehér e Mihály Vajda. Contudo, estes acabaram por romper teoricamente com o mestre e, de um modo geral, com o marxismo, o que significou duras críticas dirigidas à Lukács. Mas, o descontentamento de Lukács com a forma de exposição da Ontologia, levou-o a elaborar um novo livro que desse conta de uma exposição histórico-sistemática mais precisa, o assim chamado, Prolegomênos para uma ontologia do ser social: questões de princípios para uma ontologia hoje tornada possível (originalmente publicado em 1984) ${ }^{7}$. O esforço gigantesco de Lukács em contribuir para o "renascimento do marxismo", a partir da sua derradeira grande obra, constitui um exemplo de engajamento teórico-metodológico e político de um intelectual preocupado com os avanços do marxismo na construção de uma Ética que correspondesse plenamente com as reais aspirações humanas, bem como, da transformação radical da sociedade capitalista.

E nesse sentido, destaca Celso Frederico:

Alberto Scarponi, o tradutor da Ontologia para o italiano, na apresentação da obra procurou mostrar que Lukács, em seu último momento, debatia-se com a ideia de recriar um marxismo "fundado na realidade dos fatos". O contexto histórico das inquietações de Lukács era a nova etapa vivida pelo capitalismo após a Segunda

7 Ver o esclarecedor posfácio de Nicolas Tertulian na edição da Boitempo (2010).

\begin{tabular}{|c|c|c|c|c|}
\hline Qenita Dialectus & Ano 10 & n. 21 & Janeiro - Abril 2021 & p. $340-369$ \\
\hline
\end{tabular}


Guerra mundial. A passagem da extração da mais-valia absoluta para a relativa, alterando a forma de exploração do modo de produção capitalista, fez-se acompanhar da tentativa de controlar e manipular a consciência dos homens. Para dar conta dessa transformação histórica, Lukács voltou-se para um tema que o marxismo havia deixado de lado: a subjetividade humana. Nesse sentido [...] a Ontologia retoma, numa perspectiva renovada, vários temas centrais de História e consciência de classe (FREDERICO, 2013, p. 148, aspas e itálico no original).

Lukács na Ontologia busca destacar criticamente a manipulação inaugurada pelo capitalismo que turva a realização de uma correta apreensão da realidade, configurada no plano teórico pelo neopositivismo e aprofundada pelo fenômeno da decadência ideológica burguesa. É nesse aspecto, que a categoria da totalidade, por exemplo, tem um papel decisivo, pois, ela é a expressão das próprias determinações intrínsecas da realidade em seus traços multifacetados. No entanto, em História e consciência de classe ela comporta uma dupla determinação no sentido lógico-ontológico, abstrato-concreto; do percurso da consciência do proletariado que se torna sujeito-objeto idêntico da realidade e cancela o mundo objetivo no "místico momento final do Absoluto" hegeliano.

Por isso:

História e consciência de classe conta-nos as desventuras da consciência proletária lançada ao mundo cindido pela divisão do trabalho: o tortuoso percurso da consciência em seus embates até superar a alienação no momento final da revolução - momento de "reconciliação", de plena identidade entre sujeito (o proletariado) e o objeto (a realidade social tornada autoconsciente, que perde toda "exterioridade" em relação ao sujeito). O proletariado consciente afirma-se como um pensador coletivo que realiza "o conhecimento de si da realidade efetiva". Nesse percurso em direção à autoconsciência, a alienação é um processo necessário para que no final o proletariado possa redimir a humanidade. Mas Lukács seguia Hegel também ao identificar alienação e objetivação. Por isso, ao superar a alienação, a classe operária - o sujeitoobjeto - cancelava a própria objetividade. A realidade objetiva desaparecia ao ser incorporada no momento final da "odisseia" à consciência de classe (FREDERICO, 2013, p. 150, itálico e aspas no original).

Essa síntese precisa de Celso Frederico justifica uma questão central que suscitamos no presente artigo: que é o fato de que em História e consciência de classe, obra marcadamente de influência hegeliana, a categoria da totalidade se apresenta enquanto uma categoria que comporta uma dupla determinação teórico-metodológica, ou seja, ela é ao mesmo tempo uma categoria do pensamento (um ponto de vista do proletariado) lógico e uma determinação da realidade (uma expressão da materialidade objetiva) ontológico, pois o proletariado sujeitoobjeto idêntico da realidade conhece a si mesmo na medida que toma consciência das determinações da realidade histórico-concreta.

Nesse debate sobre os fundamentos teórico-metodológicos da categoria da totalidade em Lukács, abre-se também, aqui, uma reflexão sobre a concepção de totalidade do

\begin{tabular}{|c|c|c|c|c|}
\hline Qovista Dialectus & Ano 10 & n. 21 & Janeiro - Abril 2021 & p. $340-369$ \\
\hline
\end{tabular}


filósofo marxista tcheco Karel Kosic (1926-2003), que dá uma grande contribuição para pensarmos essa categoria enquanto a própria realidade articulada em suas leis intrínsecas, o que constitui também o fundamento da totalidade em Lukács na Ontologia.

Para Karel Kosik em seu livro A dialética do concreto (2011) a totalidade configura uma expressão concreta da realidade articulada nas suas leis intrínsecas. Pois, a totalidade busca desvelar, a aparência, a causalidade dos fenômenos e as conexões internas dialeticamente estruturadas da realidade histórico-objetiva. Dessa maneira, a totalidade apresenta-se em oposição à perspectiva do empirismo, que leva em consideração apenas as manifestações fenomênicas e causais dos processos da realidade. Para Kosik à luz da categoria da totalidade, o pesquisador pode apreender a dialética das leis e dos nexos causais dos fenômenos reais, a essência intrínseca e os aspectos fenomênicos do movimento da realidade, da constituição de suas partes e do todo, da produção e da reprodução social.

Assim, para o filósofo marxista techo, o sentido fundamental das mudanças ocorridas nas décadas anteriores, no que tange ao conceito de totalidade pode ser observado em sua declinação a uma exigência metodológica a uma regra de método na auscultação da realidade. Isso, segundo Kosik (2011), resultou na degeneração do conceito associado a duas facetas banais: "que tudo está em conexão com tudo, e que o todo é mais que as partes".

De acordo com o filósofo:

\footnotetext{
$\mathrm{Na}$ filosofia materialista a categoria da totalidade concreta é sobretudo e em primeiro lugar a resposta à pergunta: que é a realidade? E só em segundo lugar, e em consequência da solução materialista à primeira questão, ela é e pode ser um princípio epistemológico e uma exigência metodológica (KOSIK, 2011, P. 42, itálicos no original).
}

As tendências idealistas do século XX reduziram a análise da categoria da totalidade essencialmente à dimensão da relação da parte com o todo e, de forma radical desligaram a totalidade, enquanto uma exigência metodológica e um princípio epistemológico do conhecimento do real, da consideração materialista da realidade como totalidade concreta. Assim, com este desligamento, a totalidade como um fundamento metodológico perdeu sua força e congruência, perde sua necessidade, pois agora é o sujeito quem decide o fundamento ontológico de seu método apreensão do real. Por causa dessa redução, a totalidade acabou se constituindo numa representação idealista da realidade, resultando em uma apologia indireta à prevalência de análises cujo fundamento é o fragmento, uma porção da realidade, em detrimento de uma apreensão dialética que exige a compreensão da totalidade como um concreto pensado.

\begin{tabular}{|l|l|l|l|l|}
\hline Qevista Dialectus & Ano 10 & n. 21 & Janeiro - Abril 2021 & p. $340-369$ \\
\hline
\end{tabular}


A totalidade criada como uma estrutura significativa se apresenta como um processo que conforma ao mesmo tempo, a criação do conteúdo objetivo do real e a significação de todos os seus componentes e partes constitutivas, fato este que a configura uma conexão mutuamente articulada. Para Kosik (2011), dessa questão emerge o problema relativo à afirmação de qual dimensão se constituiria como uma determinação primeira no processo de compreensão da realidade objetiva, se a totalidade ou as contradições. Ou seja, o que confere prioridade à totalidade e o que confere prioridade às contradições. De acordo com Karel Kosik

O problema não consiste em reconhecer a prioridade da totalidade face às contradições, ou a das contradições face a totalidade, precisamente porque tal separação elimina tanto a totalidade quanto as contradições de caráter dialético: a totalidade sem contradição é vazia e inerte, as contradições fora da totalidade são formais e arbitrárias (KOSIK, 2011, p. 60, itálicos no original).

As contradições e a totalidade formam uma unidade dialética mediada por uma interação dinâmica recíproca. Dessa forma, o que separa efetivamente a concepção materialista da totalidade da concepção estruturalista, por exemplo, é que a concreticidade da totalidade é determinada pelas contradições histórico-sociais e, a legalidade imanente própria das contradições que residem na categoria da totalidade. Portanto, a totalidade como princípio metodológico constitutivo do método dialético materialista, reside no entendimento de que a totalidade é a totalidade unitária da base e da superestrutura com seus movimentos, processos, influências mútuas e relações diversas, sendo a base o seu elemento preponderante em última instância. Do contrário, a totalidade se torna abstrata e vazia. Entende-se dessa maneira, que a totalidade concebida à luz do materialismo histórico é produto da sociabilidade eminentemente humana.

O homem é um sujeito histórico-social que no processo de produção e reprodução de sua existência material é, criador da base e da superestrututa outrora citadas. Produz a realidade social como um conjunto de relações sociais, instituições e ideias. Neste processo de criação da realidade objetiva também produz a si mesmo, como um ser histórico-social, provido de sentidos e poderes eminentemente humanos, realizando o processo contínuo da "humanização do homem".

Conforme destaca Kosik: “[...] A totalidade concreta como concepção dialéticomaterialista do conhecimento do real [...] significa, portanto, um processo indivisível, cujos momentos são: a destruição da pseudoconcreticidade, isto é, da fetichista e aparente objetividade do fenômeno, e o conhecimento de sua autêntica objetividade [...]" (KOSIK, 2011,

\begin{tabular}{|l|l|l|l|l|}
\hline Qevista Dialectus & Ano 10 & n. 21 & Janeiro - Abril 2021 & p. 340 - 369 \\
\hline
\end{tabular}


p. 61, itálico no original). A realidade concreta é assim, um produto da práxis humana objetivosubjetiva, que se desenvolve num processo dialético constitutivo imanente da própria realidade historicamente determinada pelos sujeitos sociais em suas relações reais.

Nessa linha de raciocínio, os teóricos Michel Löwy e Samir Naïr coautores do livro Lucien Goldmann ou a dialética da totalidade (2008) discutem os fundamentos da categoria da totalidade no pensamento do filósofo e sociólogo francês de origem judaico-romeno. Para estes autores, "A obra de Lucien Goldmann, assim como a do jovem Lukács, encontra-se sob o signo da categoria da totalidade”. Dessa forma:

Desde Introducion á la philosophie de Kant, ele lembra que a totalidade na filosofia marxista não é determinável in abstracto, como uma equação algébrica. A totalidade remete não a um modelo teórico, abstrato e formal, mas a uma realidade histórica em construção. Ela é um processo contínuo. O sujeito que faz questão de "construir" teoricamente essa totalidade é, ele próprio, um momento desse processo: dele participa plenamente. Daí um princípio fundamental que separa radicalmente o procedimento dialético de qualquer outra forma de pensamento, a saber, a impossibilidade de ter um olhar externo em relação à totalidade (LÖWY e NAÏR, 2008, p. 23, itálico e aspas no original).

Essa reflexão nos permite entender ainda mais plenamente, que no marxismo a categoria da totalidade é uma expressão da própria realidade histórico-concreta, ou melhor, ela é a própria realidade concreta em seus traços mais essenciais e constitutivos, pois, o sujeito que a concebe, como dizem os autores, é ele mesmo um "momento" desse processo incessante. O sujeito é a própria totalidade, enquanto parte integrante de um todo que se desenvolve dialeticamente em cada situação histórico-concreta. O sujeito, portanto, contém traços constitutivos das contradições que compõem a totalidade, carrega consigo, em maior ou menor intensidade, características dos processos parciais que regem a constitutividade desta totalidade.

A sociedade, portanto, é um todo histórico em movimento contínuo, criada pelos sujeitos sociais a partir de seus atos singulares cotidianos em suas relações reais. Nesse sentido, engendram processos políticos, culturais, econômicos, éticos, morais, estéticos etc. que constituem uma totalidade objetiva e complexa, unitária. Neste sentido, argumentamos com Lukács (1966, p. 21, tradução nossa), que "a filosofia materialista não considera que as formas de objetividade das categorias correspondentes aos objetos e suas relações, sejam produtos de uma consciência criadora" ${ }^{\prime}$, pelo contrário, entendemos que a realidade é unitária e feita apenas por ações eminentemente humanas, uma unidade da diversidade. Portanto, os reflexos do real,

8 No original: la filosofia materialista no considera que las formas de la objetividad, las categorías correspondientes a los objetos e sus relaciones, sean productos de una consciencia creadora. (LUKÁCS, 1966, p. 21)

\begin{tabular}{|l|l|l|l|l|}
\hline Qenista 2 Oialectus & Ano 10 & n. 21 & Janeiro - Abril 2021 & p. 340 - 369 \\
\hline
\end{tabular}


sejam eles estéticos ou científicos, terão de necessariamente se comportar objetivamente dentro desta unidade total, haja vista que, como afirma Lukács (1966, p. 21, tradução nossa), "todas as divergências e mesmo oposições que se apresentam nos diversos modos de reflexo tem de se desenvolver no marco desta realidade material e formalmente unitária."9

Assim: "Em oposição ao idealismo hegeliano e seguindo a esteira de Marx e Lukács, Goldmann concebe que a totalidade não é regida pelo movimento do Espírito que culmina no Saber Absoluto", pois nesse caso, a totalidade se submeteria "ao princípio interno de seu próprio processo, obedeceria à lei da evolução do conceito e não à da realidade". A realidade concreta do mundo seria tão somente "um epifenômeno da ideia", o objeto estaria inteiramente incorporado no sujeito. Em outro sentido, "a realidade seria uma determinação, senão um produto da consciência". Com efeito, "[...] A identidade total entre subjetividade e a objetividade existiria, via de regra, no sentido de uma dissolução do mundo da materialidade no mundo da espiritualidade" (LÖWY e NAÏR, 2008, p. 24, itálico nosso).

Para Goldmann, segundo Michel Löwy e Samir Naïr, a totalidade constitui uma "realidade universal", que incorpora tanto a "materialidade" como a "espiritualidade". E no que diz respeito, a relação entre essas duas determinações, há uma complexidade que não se pode escamotear: o fato de que ela não configura "uma identidade absoluta e total". Desse modo, essa relação,

É antes submetida a um princípio de relatividade e de equilíbrio: até e inclusive contra o jovem Lukács, que estabeleceu, à maneira de Hegel, a identidade total entre o sujeito e o objeto, Goldmann sustenta o que ele denomina "a identidade parcial entre sujeito e objeto". Em outras palavras, ele enfatiza a existência de uma autonomia relativa entre a consciência e a realidade, entre o sujeito e o objeto. Nesse caso, a consciência não é mais o produto puro da subjetividade criadora, ela é o resultado da relação entre a subjetividade e a objetividade [...] (LÖWY e NAÏR, 2008, p. 24, aspas e itálico no original).

A totalidade para Goldmann, conforme os autores, não poderia ser dada objetivamente, mas antes ela é um produto da atividade histórico-social dos indivíduos. Ela não é resultado da pura atividade da consciência humana; mas da relação concreta e dialética entre subjetividade e objetividade.

Para Louis Altuhsser em Por Marx (2015), contudo, o todo é um “complexo estruturado já dado", um conceito que pode ser construído cientificamente. Pois, enquanto um racionalista moderno, Althusser entende que “[...] a totalidade é um conceito cujo conteúdo é

9 No original: todas las divergencias y hasta contraposiciones, que se presentan em los diversos modos de reflejo tienen que desarrollarse en el marco de esa realidad material y formalmente unitaria. (LUKÁCS, 1966, p. 21) 
perceptível de acordo com o rigor da análise científica” (ALTHUSSER, 2015, p. 24, itálico no original). Ou seja, em Althusser a categoria da totalidade, enquanto um dado objetivo, é "elevada ao patamar de axioma central da análise teórica".

Nas palavras de Althusser:

[...] Se toda contradição o é de um todo complexo estruturado com dominante, não se pode considerar o todo complexo fora de suas contradições, fora da relação de desigualdade fundamental entre elas. Dito de outro modo, cada contradição, cada articulação essencial da estrutura e a relação geral das articulações dentro da estrutura com dominante constituem igualmente condições de existência do próprio todo complexo. Essa proposição é de primeiríssima importância, pois significa que a estrutura do todo - logo, a "diferença" das contradições essenciais e sua estrutura com dominante - é a própria existência do todo: que a "diferença" das contradições (que haja uma contradição principal etc., e que cada contradição tenha um aspecto principal) componha uma unidade com as condições de existência do todo complexo (ALTHUSSER, 2015, p. 164-1655, aspas no original).

Para Althusser, a existência de uma contradição principal, ou maior e sua estrutura com dominante, se expressa pela relação dialética das contradições desiguais, ou diferentes. As contradições desiguais no interior de si mesmas constituem a unidade do todo. "Esse condicionamento", afirma Althusser,

[...] não desemboca, em sua aparente circularidade, na destruição da estrutura de dominação que constitui a complexidade do todo e sua unidade. Muito pelo contrário, ele é, no interior mesmo da realidade das condições de existência de cada contradição, a manifestação dessa estrutura com dominante que constitui a unidade do todo. Essa reflexão das condições de existência da contradição no interior de si mesma, essa reflexão da estrutura articulada com dominante que constitui a unidade do todo complexo no interior de cada contradição, eis o traço mais profundo da dialética marxista [...] (ALTHUSSER, 2015, p. 165, itálico no original).

De acordo com Althusser, as condições são tão somente a existência atual do "todo complexo", pois, elas são as suas próprias contradições, "refletindo cada uma em si a relação orgânica" que estabelecem unas com as outras na "estrutura com dominante do todo complexo". Mas, como asseguram Löwy e Naïr (2008, p. 24-25): “A relação entre a forma e o conteúdo é esmaecida em benefício apenas da percepção da forma. O princípio da contradição é suprimido; a totalidade perdeu sua alma. Ela é simplesmente um modelo abstrato".

Assim, segundo estes autores:

Em oposição tanto ao idealismo metafísico como ao racionalismo positivista e estruturalista, Goldmann sustenta que a totalidade não poderia ser objetivamente dada, mas que, em sua essência, é produto da atividade humana [...] A ação humana é um eterno processo de transformação da totalidade: por isso, para apreender a realidade, o homem procede por totalizações relativas sem jamais alcançar a objetividade pura e cristalina. Ele próprio é história. E é por esse processo, que consiste em atingir certa coerência estrutural, que o homem destrói as totalidades antigas para criar novas. "Só

\begin{tabular}{|c|c|c|c|c|}
\hline Revista Dialectus & Ano 10 & n. 21 & Janeiro - Abril 2021 & p. $340-369$ \\
\hline
\end{tabular}


existir totalização na medida em que há destotalização". Portanto, a totalidade é processo histórico contínuo. Ela é regida pelo princípio de variação interna, não de fixação das partes. A relação entre o conteúdo e a forma é consequentemente uma relação dialética, no sentido em que a forma é o resultado indireto do conteúdo (LÖWY e NAÏR, 2008, p. 25, itálico e aspas no original).

Isso significa que a forma deriva igualmente do processo de transformação do conteúdo. Os efeitos do conteúdo sobre a forma são destituídos de linearidade. O que de outro modo significa que existe uma "interdependência" de "ação" e "retroação", um movimento unitário de determinação recíproca. Löwy e Naïr (2008, p. 25) sustentam que se "a totalidade é submetida então a um processo de variação, as estruturas internas [...] jamais existem de maneira absoluta, elas próprias estão sempre em processo de transformação e de mutação". Ou seja, esse processo é caracterizado pela passagem ou superação da "quantidade" pela "qualidade", da transformação de uma estrutura para outra. Nesse aspecto, a condição da estrutura - da parte - é determinada em última instância pela totalidade e não o oposto. Pois, o movimento é a lei de "transformação" e de "mutação" da estrutura do todo. Daí resulta que a própria estrutura se constitui num processo de estruturação.

A totalidade na perspectiva de Goldmann, segundo Löwy e Naïr, é fundamentalmente dialética, e não uma totalidade formal. Portanto, essa é a base do pensamento de Goldmann: totalidade dialética. Nesse quadro teórico a totalidade em Goldmann não constitui um conceito, mas sim, uma “categoria metodológica". E ele vai tomar como referência a concepção de totalidade em Lukács em História e consciência de classe, quando afirma que o fundamento da totalidade é o predomínio do todo sobre as partes que a compõe. Assim, “[...] o conhecimento das partes é determinado [...] pelo Todo, da mesma maneira que a compreensão do Todo remete ao conhecimento das partes e de sua combinação, de seu sistema de relações" (LÖWY e NAÏR, 2008, p. 26).

Para Goldmann, a compreensão dos fatos humanos - pois ele considera que tudo o que é praticado pelos homens constitui um fato humano - somente pode ser apreendido corretamente "mediante sua inserção em estruturas gerais"; espaciais e temporais, das quais o indivíduo é parte integrante, desse modo, o entendimento das próprias estruturas remete ao "estudo de seus componentes", isto é, do que Goldmann designa como totalidades parciais e relativas. De acordo com Löwy e Naïr, Goldmann submete o conhecimento de um fato a um par categorial que é compreensivo-explicativo ${ }^{10}$.

10 De acordo com o próprio Goldmann: Temos a mesma posição de Marx e Lukács. [...] [A opinião destes] nos parece incomparavelmente mais clara. A identidade do sujeito e do objeto dá às ciências do homem um estatuto diferente das ciências da natureza. Ela faz de toda afirmação sobre a realidade humana uma intervenção prática,

\begin{tabular}{|l|l|l|l|l|}
\hline Qenista Dialectus & Ano 10 & n. 21 & Janeiro - Abril 2021 & p. $340-369$ \\
\hline
\end{tabular}


A compreensão dos fatos históricos, para o marxismo, de acordo com Goldmann, requer, enquanto uma condição fundamental, não apenas uma compreensão desses fatos, mas também, sua explicação. Assim, por meio de um "movimento contínuo", passa-se da compreensão de um fenômeno histórico-social para a sua explicação. Reproduzimos aqui uma inescapável citação de Goldmann (de usa obra Marxismo e ciências humanas, 1970), contida no livro de Löwy e Naïr que nos permite entender com clareza essa questão metodológica:

[...] a compreensão é a evidenciação de uma estrutura significativa imanente ao objeto estudado [...]. A explicação é simplesmente a inserção dessa estrutura, enquanto elemento constitutivo e funcional, em uma estrutura imediatamente globalizante, que o pesquisador não explora, no entanto, de maneira detalhada, mas somente na medida em que isso é necessário para tornar inteligível a gênese da obra que ele está estudando. Entretanto, basta tomar como objeto de estudo a estrutura globalizante para que o que era explicação se torne compreensão e para que a pesquisa explicativa tenha de se reportar a uma nova estrutura ainda mais ampla. A título de exemplo: compreender os Pensamentos de Pascal ou as tragédias de Racine é evidenciar a visão trágica que constitui a estrutura significativa que rege o conjunto de cada uma dessas obras; mas compreender a estrutura do jansenismo extremista é explicar a gênese dos Pensamentos e as tragédias racinianas. Da mesma maneira, compreender o jansenismo é explicar a gênese do jansenismo extremista; compreender a história da nobreza de toga no século XVII é explicar a gênese do jansenismo; compreender as relações de classe na sociedade francesa do século XVII é explicar a evolução da nobreza de toga etc. (LÖWY e NAÏR apud GOLDMANN, 2008, p. 27, itálico no original).

Nessa passagem de Goldmann, podemos perceber que a pesquisa social nas ciências

humanas deve ser desenvolvida em dois planos principais: o primeiro diz respeito ao objeto pesquisado, o fenômeno especificamente falando e o segundo, no plano da estrutura globalizante. Sendo assim, teremos: "Na análise, a compreensão é uma primeira etapa que dá conta da constituição interna da estrutura, ela é imanente. É uma interpretação. Em compensação, a explicação é externa à interpretação" (LÖWY e NAÏR, 2008, p. 27, itálico no original), ou seja, ela é “extrínseca”. Aqui entendemos que esse método de pesquisa tem como

uma práxis, que torna impossível a separação dos julgamentos de fato e dos julgamentos de valor. Daí resulta, que um conhecimento positivo dos fatos humanos implica sempre uma tomada de decisão e um estudo às vezes explicativo e compreensivo. Dada estas condições, o problema de uma epistemologia das ciências humanas torna-se aquela de um estudo também avançado que possibilita caracteres específicos desse tipo de saber conceitual, que é essencialmente diferente daqueles que caracterizam, respectivamente, de uma parte a lógica formal e as matemáticas e de outra parte às ciências da natureza, mas que não é de modo algum um não-saber (GOLDMANN, 1970, p. 254, tradução nossa, itálico no original). No original: Nous avouons que la position de Marx et Lukács [...] nous paraît incomparablement plus claire. L'identité du sujet et de l'objet crée aux sciences de l'homme un statut différent des sciences de la nature. Elle fait de toute affirmation sur la réalité humaine une intervention pratique, une praxis, qui rend impossible la séparation des jugements de fait et des jugements de valeur. Il s'ensuit qu'une connaissance positive des fait humains implique toujours une prise de position et une étude à la fois explicative et compréhensive. Das ces conditions, le problème d'une épistémologie des sciences humaines devient celui d'une étude aussi avancée que possible des caractères spécifiques de ce type de savoir conceptuel, qui est essentiellement différent de ceux qui caractérisent respectivement d'une part la logique formelle et les mathématiques et d'autre part les sciences de la nature, mais qui n'est nullement un non-savoir (GOLDMANN, 1970, p. 254, itálico no original).

\begin{tabular}{|l|l|l|l|l|}
\hline Q & Ano 10 & n. 21 & Janeiro - Abril 2021 & p. $340-369$ \\
\hline
\end{tabular}


principal fundamento, em seu caráter geral, o recurso ao contexto "histórico", "social" e "cultural" que permeia toda a estrutura. Portanto, esse processo dialético "compreensãoexplicação" constitui um pressuposto metodológico central, que deixa evidente o aspecto "funcional" da parte, da estrutura, na totalidade. Essas estruturas explicitam, por regra, o modo de agir dos homens face aos problemas que se colocam para eles. Em virtude disso, eles ocupam uma "função" na esfera da totalidade. Esse laço inquebrantável entre função e estrutura constitui a principal manifestação da dimensão histórica do modo de agir da humanidade.

\section{Conforme sustentam Löwy e Naïr:}

Como Lukács, Goldmann não cansa de salientar a afinidade entre a dialética marxista e a dialética hegeliana. No entanto, afirma que constituem duas visões distintas do mundo. Por quê? A diferença que se alega usualmente (o próprio Marx fez isso), a saber, que Hegel proclama a primazia do espírito e Marx, a da vida econômica, não é suficiente [...] para fazer do hegelianismo e do marxismo duas filosofias distintas. Pois Marx admite a influência do pensamento sobre a vida material e Hegel, a influência das condições sociais sobre a vida espírito. Haveria então a mesma dialética da totalidade, e a diferença se reduziria, no máximo, a uma importante questão de ênfase (LÖWY e NAÏR, 2008, p. 83, itálico no original).

O Lukács que Goldmann faz referência é o de História e consciência de classe, obra na qual o filósofo húngaro resgata a dialética hegeliana para restituir ao marxismo o seu aspecto, dialético ${ }^{11}$ e dinâmico, ceifado pelo dogmatismo stalinista que via em Hegel uma influência conservadora. Nesse sentido, a categoria da totalidade é alçada por Lukács como o elemento central constitutivo no método dialético de Marx. Isso é bastante relevante, muito embora, essa perspectiva da totalidade em Lukács de 1923, tenha mais influência de Hegel do que Marx. Não obstante, essa categoria consiste numa expressão da consciência do proletariado; um ponto de vista que, um "ângulo visual", que permite ao proletariado conceber a sociedade enquanto uma totalidade concreta, mas pelo viés de uma concepção duplamente determinada no sentido lógico-ontológica e abstrato-concreta com uma forte inclinação idealista, ou seja, o

11 Goldmann ainda destaca que: Heidegger, desenvolveu uma filosofia dualista da história, separou radicalmente o ontológico do ôntico, a filosofia das ciências positivas [...]; monista, fiel a Hegel e Marx, Lukács recusa toda separação deste gênero, criticando todo o positivismo, toda ideia de ciência no indicativo e toda metafísica, toda teoria filosófica que se queira conceitualmente fechada e separada da ação e da totalidade, exigia uma ciência filosófica e uma filosofia científica e positiva e não pretendia desenvolver a um nível puramente conceitual uma ontologia marxista da história Cada uma dessas duas posições é coerente e era defendida no interior da filosofia de seus adeptos (GOLDMANN, 1970, p. 262, tradução nossa). No original: Il restait cependant entre Marcuse et Lukács une différence importante. Heidegger, développant une philosophie dualiste de l'historie, séparait radicalment I'ontologique de l'ontique, la philosophie des sciences positives [...]; moniste, fidéle en cela à Hegel et à Marx, Lukács refusait toute sépation de ce genre, et tout em critiquant tout pisitivisme, toute idée de science à l'indicatif et toute métaphysique, toute théorie philosophique se voulant conceptuellement fermée et séparée de l'action et de la totalité, exigeait une science philosophique et une philosophie scientifique et positive et n'envisageait même pas qu'on puisse développer à un niveau purement conceptuel une ontologie marxiste de l'histoire. Chacune de ces deux positions était cohérente et se défendait à l'intérieur de la philosophie respective de leurs tenants (GOLDMANN, 1970, p.262).

\begin{tabular}{|c|c|c|c|c|}
\hline Rovita Dialectus & Ano 10 & n. 21 & Janeiro - Abril 2021 & p. $340-369$ \\
\hline
\end{tabular}


ponto de partida efetivo não é realidade concreta, mas a consciência de classe do proletariado sujeito-objeto idêntico da realidade histórica.

De fato, podemos afirmar que os princípios gerais da totalidade em Lukács em História e consciência de classe são conservados no sentido da superação crítica de Hegel na Ontologia: contradição, movimento, historicidade, a reciprocidade dialética entre as partes e $o$ todo etc. Todavia, na passagem progressiva em relação ao aspecto teórico-metodológico decisivo, Lukács avança na fundamentação da categoria da totalidade rumo a um novo sentido plenamente ontológico, objetivo, e não mais com base numa dupla determinação, um postulado do pensamento lógico-ontológico, abstrato-concreto. Dessa forma, Lukács corrige, na sua Ontologia do ser social, os problemas que essa duplicidade da categoria da totalidade comporta no livro de 1923.

Löwy e Naïr, afirmam que Goldmann estabelece a diferença de ênfase (entre a dialética marxista e a dialética hegeliana) baseando-se em um problema mais relevante, que evidencia a radical distinção entre essas duas filosofias:

[...] a relação entre o pensamento e a ação. Os dois sistemas afirmam a unidade do pensamento e da ação, mas de maneira inteiramente diferente. Para Hegel, a ação não exige necessariamente um pensamento consciente de si mesma, um ser "em si e para si”. O “artifício da razão" impõe-se através das consciências mais ou menos falsas dos homens, e a verdadeira tomada de consciência somente se dá depois, post factum, quando a ideia já foi realizada na realidade histórica. A filosofia de Hegel pensa e compreende Napoleão ou o Estado prussiano, mas não é um meio indispensável para a sua realização. Para Marx, se é verdade que existem ideologias, falsas consciências através das quais se realiza a marcha da história, a verdadeira libertação (ou seja, a revolução socialista) implica uma tomada de consciência verdadeira; o pensamento torna-se assim um elemento necessário e não, como em Hegel, o coroamento da ação, a coruja de Minerva, que desperta depois que o dia cai. Para Marx, o pensamento verdadeiro não é a realização do espírito absoluto, o fim da história, mas a condição para uma ação eficaz de transformação social (LÖWY e NAÏR, 2008, p. 83-84, itálico e aspas no original).

De fato, esse fundamento de diferenciação é coerente, embora, entendamos que é mais do que uma questão de ênfase a diferença entre a dialética marxista e a dialética hegeliana, como é colocada por Löwy e Naïr com base em Goldmann. O argumento para sustentar nossa posição nesse debate é baseado no que o próprio Marx afirma com relação a essa diferença (que não é só diferente, mas, diametralmente oposto) do seu método e o de Hegel. Em Marx a dialética é concebida, fundamentalmente, em termos materialistas. Seus fundamentos estão ancorados na constatação ontológica de que a realidade é uma materialidade objetiva e processual; historicamente constituída pelos homens em suas relações de produção e ações concretas, socialmente fundadas pelo ato do trabalho. A dialética em Marx assume, dessa forma,

\begin{tabular}{|c|c|c|c|c|}
\hline Qovista Dialectus & Ano 10 & n. 21 & Janeiro - Abril 2021 & p. $340-369$ \\
\hline
\end{tabular}


uma configuração objetiva que considera o ser social, a realidade concreta, suas relações e processos, um todo dialeticamente estruturado.

A este respeito, afirma Lukács (1966, p. 16, tradução nossa), que:

[...] os métodos do materialismo dialético indicam com claridade quais são os caminhos, e como percorrê-los, quando se quer elevar a realidade objetiva ao conceito, em sua verdadeira objetividade e profundidade, na essência de um determinado território de acordo com sua verdade. Apenas realizando e mantendo este método, mediante a própria investigação, é que a orientação desses caminhos oferece a possibilidade de tropeçar com o que se busca [...] nenhuma outra coisa conseguirá aquele que alimenta a ilusão de poder, com uma simples interpretação de Marx, reproduzir a realidade e, ao mesmo tempo, a concepção desta realidade por Marx. Os objetivos só podem ser alcançados mediante uma consideração sem julgamentos da realidade, por meio de sua elaboração com os métodos descobertos por Marx: Fidelidade à realidade e fidelidade ao marxismo. ${ }^{12}$

Marx, n'O capital $^{13}$, afirma, por exemplo, que seu método (dialético) é o oposto do método de Hegel e, é desse confronto, que podemos ter uma ideia mais nítida da especificidade da dialética em Marx:

Meu método dialético, em seus fundamentos, não é apenas diferente do método hegeliano, mas exatamente seu oposto. Para Hegel, o processo de pensamento, que ele, sob o nome de Ideia, chega mesmo a transformar num sujeito autônomo, é o demiurgo do processo efetivo, o qual constitui apenas a manifestação externa do primeiro. Para mim, ao contrário, o ideal não é mais que o material, transposto e traduzido na cabeça do homem (MARX, 2013, p. 90).

Essa consideração de Marx evidencia que a sua dialética foi recolhida do embate crítico com a concepção da dialética de Hegel. Todavia, acerca dessa relação, damos relevo ao que Herbert Marcuse chama a atenção: “que a concepção dialética da realidade, de Marx, foi motivada, originalmente, pelo mesmo dado que a de Hegel, qual seja, o do caráter negativo da realidade" (MARCUSE, 2004, p. 268-269). Marcuse quer dizer com isso, que no mundo social este caráter negativo produz os antagonismos da sociedade dividida em classes sociais e, que esse processo, continua sendo a força motriz do avanço social.

12 No original: [...] los métodos del materialismo dialéctico indican com claridad cuáles són los caminos y cómo hay que recorrerlos si se quiere llevar la realidad objetiva a concepto, em su verdadera objetividad, y profundizar em la esencia de um determinado território de acuerdo com su verdad. Sólo realizando y manteniendo mediante la propria investigación, esse método, la orientación de eses caminos, se ofrece la possibilidad de tropezar com lo buscado [...] Ni uma ni outra cosa conseguirá el que alimente la ilusión de poder, com uma simple interetación de Marx, reproducir la realidade y, al mismo tiempo la concepción de ésta por Marx. Los objetivos sólo pueden conseguirse mediante uma consideración sin prejuicios de la realidad mediante su elaboración com los métodos descubiertos por Marx: fidelidad a la realidad y fidelidad al marxismo. (LUKÁCS, 1966, p. 16)

13 Especificamente no Posfácio da segunda edição.

\begin{tabular}{|l|l|l|l|l|}
\hline Qevista Dialectus & Ano 10 & n. 21 & Janeiro - Abril 2021 & p. 340 - 369 \\
\hline
\end{tabular}


Nesse sentido, cada fato, cada processo singular comporta um modo específico de significação que, só pode ser apreendido, quando vistos dentro de uma totalidade na qual estão integrados. Portanto, “para Marx, como para Hegel, 'a verdade' só se encontra no todo, na totalidade "negativa""14 (MARCUSE, 2004, p. 269). A totalidade que a dialética marxiana alcança, sendo assim concebida, é uma totalidade que comporta os antagonismos da sociedade de classes. A dialética materialista prefigura os fatos como aspectos inerentes de uma totalidade histórica da qual "não se podem isolar".

Para Marx, a dialética é uma processualidade objetiva arraigada no próprio ser objetivo. "O ser objetivo atua objetivamente e não atuaria objetivamente se o objetivo (Gegenständliche) não estivesse posto em sua determinação essencial” (MARX, 2010, p. 126). O homem em suas determinações essenciais é um ser "corpóreo", dotado de forças naturais, efetivo, objetivo, sensível, o que significa diz Marx, que ele tem externo a si “objetos sensíveis", efetivos "como objetos de seu ser", produtos de sua práxis objetivo-subjetiva; como manifestação de sua existência social.

A este respeito, Lukács (1966, p. 26, tradução nossa) ${ }^{15}$, argumenta que:

Um complexo de fenômenos não pode ser considerado cientificamente conhecido senão quando aparece totalmente conceituado a partir de suas propriedades imanentes, das legalidades imanentes que operam nele. $\mathrm{Na}$ prática, como é natural, uma tal plenitude de conceituação é sempre apenas aproximada; A extensa e intensiva infinidade de objetos, suas relações estáticas e dinâmicas, etc., não permitem conceber como absolutamente definitivo nenhum conhecimento, em nenhuma forma, nem pensar que possa estar isento a qualquer correção, limitação, extensão, etc.

O método dialético de Marx em suas determinações fundamentais visa se apropriar das determinações intrínsecas da coisa mesma; das conexões internas dos fenômenos, suas

14 Marcuse esclarece que: O mundo social, porém, só se torna uma totalidade negativa no processo de uma abstração que se impõe ao método dialético pela estrutura daquilo a que ele se refere, a sociedade capitalista. Podemos mesmo dizer que a abstração é obra própria do capitalismo, e que o método marxista apenas dá continuação a este processo. A análise de Marx mostrou que a economia capitalista se constrói sobre e se perpetua pela redução constante do trabalho concreto a trabalho abstrato [...] O mundo das mercadorias é um mundo 'falsificado' e 'mistificado', e a análise crítica deste mundo deve começar por acompanhar as abstrações que o constituem devendo, pois, partir destas relações abstratas para atingir o seu conteúdo real [...] De acordo com isto, a teoria marxista elabora, em primeiro lugar, as relações abstratas que determinam o mundo das mercadorias (tais como mercadoria, valor de troca, dinheiro, salários) e delas retorna ao seu conteúdo plenamente desenvolvido do capitalismo [...] (MARCUSE, 2004, p. 269, itálico no original).

15 No original: Um complejo de fenómenos no puede considerarse científicamenente conocido sino cuando aparece totalmente conceptuado a partir de sus propriedades inmanentes, de las legalidades inmanentes que obran em él. Em la prática, como es natural, una tal plenitud de conceptuación es siempre sólo aproximada; la infinitud extensiva e intensiva de os objetos, sus relaciones estáticas y dinámicas, etc., no permiten concebir como absolutamente definitivo ningún conocimiento, em ninguna forma, ni pensar que pueda esta exento alguma vez de correcciones, limitaciones, ampliaciones, etc. (LUKÁCS, 1966, p. 26)

\begin{tabular}{|c|c|c|c|c|}
\hline Qevista Dialectus & Ano 10 & n. 21 & Janeiro - Abril 2021 & p. $340-369$ \\
\hline
\end{tabular}


relações e formas de desenvolvimento. O objetivo de Marx é apreender idealmente o movimento efetivo da realidade. A apropriação mental do conteúdo concreto do real. Para tanto, Marx afirma que seu método constitui um caminho do abstrato ao concreto. Por meio de sucessivas aproximações ao objeto (concreção real), vai compondo um todo articulado; do dado caótico imediato de um todo ao "concreto pensado" rico de determinações e relações diversas. Aqui nos referimos ao que Lukács (1966) chamou de pesquisa de gênese, ou método histórico e sistemático, e a capacidade deste arcabouço categorial de refletir a história humana na consciência dos homens. Neste sentido, estamos convencidos de que se quisermos compreender a gênese e peculiaridade do real concebendo-o como um concreto pensado, o método histórico e sistemático é irremediavelmente inevitável.

O concreto é concreto porque é uma síntese de muitas determinações, isto é, unidade do diverso. Por isso, o concreto aparece no pensamento como o processo de síntese, como resultado, não como ponto de partida, embora seja o verdadeiro ponto de partida e, portanto, o ponto de partida também da intuição e da representação (MARX, 2008, p.258-259).

Aqui Marx demarca mais uma vez a diferença de seu método em relação ao de Hegel. Hegel, diz Marx (2008), caiu na ilusão de conceber o real como produto do pensamento que se determina em si, origina-se de si; é auto movente. Sendo que o método (dialético materialista) consiste em "elevar-se do abstrato ao concreto", pois, é a maneira correta de proceder do pensamento que se apropria efetivamente do conteúdo concreto da cosia concreta. Por isso, Marx (2008) assevera que até a mais simples categoria econômica, como por exemplo, o valor de troca, pressupõe a população. Esta população que por sua vez, produz em determinadas condições sociais e históricas, como também, alguns tipos de famílias, comunidade e Estados, pois, a "população é uma abstração se deixo de lado as classes que a compõem $[\ldots]$...'

$\mathrm{Na}$ dialética materialista o mundo, a realidade objetiva é concebida como uma totalidade concretamente articulada; em movimento. E o papel do pensamento é reproduzir esse movimento efetivo, contraditório, dinâmico do real. A forma pela qual o pensamento se apropria dessa realidade concreta se dá pela mediação categorial. As categorias como "formas de ser"; expressões de relações concretas; determinações da própria existência. Assim, Para Marx, diferentemente de Hegel, a realidade não é produto do pensar, da ideia que se autocria; que se engendra a si mesma. A realidade é produto de relações concretas que os homens estabelecem 
entre si em suas relações de produção e da transformação da natureza por meio do seu ato de trabalho.

Marx, já no prefácio de Contribuição à crítica da economia política (1859) destaca dessa forma que:

[...] na produção social da própria existência, os homens entram em relações determinadas, necessárias, independentes de sua vontade; essas relações de produção correspondem a um grau determinado de desenvolvimento de suas forças produtivas materiais. A totalidade dessas relações de produção constitui a estrutura econômica da sociedade, a base real sobre a qual se eleva uma superestrutura jurídica e política e à qual correspondem formas sociais determinadas de consciência. O modo de produção da vida material condiciona o processo de vida social, política e intelectual. Não é a consciência dos homens que determina o seu ser; ao contrário, é o seu ser social que determina sua consciência (MARX, 2008, p. 47, itálico nosso).

A dialética materialista permite que o pensamento se oriente de forma concreta no sentido de capturar os nexos efetivos do todo social. Esse todo se apresenta como resultado da própria realidade enquanto realidade material. Este postulado da totalidade concreta, em Marx, como uma perspectiva metodológica de pesquisa dialética da realidade social, constitui numa assertiva em que todos os fenômenos da realidade podem ser apreendidos como um todo estruturado. Todo fato social, portanto, prefigura um processo histórico, quando é entendido como um momento do todo. A conexão entre a parte e o todo; a singularidade e a universalidade mediada dialeticamente por processos que interagem entre si, com todas as suas relações e contradições intrínsecas, sugere um sentido ontológico imanente à própria estrutura hierárquica do mundo real, à relação dialética entre aparência e essência e à relação entre sujeito e objeto no processo de conhecimento (KOSIK, 2011).

O pensamento dialético tem como ponto de partida o pressuposto de que o conhecimento humano se desenvolve num movimento dinâmico e contraditório, onde sujeito e objeto se determinam mutuamente. A realidade estruturada num todo significa que um conhecimento concreto da própria realidade não configura "um acrescentamento sistemático de fatos a outros fatos, e de noções a outras noções” (KOSIK, 2011, p. 50). Na concepção dialética o real é compreendido e prefigurado como uma totalidade que não se constitui apenas como uma soma de relações, fatos e processos, mas também como a sua produção, estrutura e formação. À totalidade dialética, nos informa Kosik (Idem, p. 51), "pertence a criação do todo e a criação da unidade, a unidade das contradições e a sua gênese".

Para a dialética materialista a realidade social pode ser apreendida em sua objetividade; em sua totalidade concreta, quando se evidencia a estrutura essencial da realidade social em si mesma; quando a pseudoconcreticidade é suprimida, quando se conhece a

\begin{tabular}{|l|l|l|l|l|}
\hline Qevista Dialectus & Ano 10 & n. 21 & Janeiro - Abril 2021 & p. 340 - 369 \\
\hline
\end{tabular}


reciprocidade dialética entre base e superestrutura e o homem enquanto sujeito da história. $\mathrm{O}$ homem concebido enquanto sujeito histórico-social, como sujeito da práxis objetiva humana é o fundamento, portanto, da compreensão da realidade social como uma totalidade dialeticamente articulada.

Na base desses postulados, Marx argumenta que "[...] Os homens são produtores de suas representações. De suas ideias e assim por diante, mas os homens reais, ativos, tal como são condicionados por um determinado desenvolvimento de suas forças produtivas e pelo intercâmbio que a ele corresponde [...]” (MARX-ENGELS, 2007, p. 94). Esse postulado materialista, que está na base da dialética marxiana, representa o fundamento da realidade histórico-concreta. Ele aponta para a relação entre ser o e a consciência dos homens no contexto de suas relações sociais. Certamente os homens pensam; imaginam; simbolizam representam, todavia, afirma Marx, não se parte do homem imaginado, representado, mas do homem real, concreto, efetivo em suas relações reais de vida. Pois, “[...] Do mesmo modo que não se julga o indivíduo pela ideia que de si mesmo faz, tampouco se pode julgar uma tal época de transformações pela consciência que ela tem de si mesma. É preciso, ao contrário, explicar essa consciência pelas contradições da vida material, pelo conflito que existe entre as forças produtivas e as relações de produção" (MARX, 2008, p. 48).

Confirmamos com Lukács em sua Ontologia do ser social que, "para Marx a dialética não é apenas um princípio cognitivo, mas constitui a legalidade objetiva de toda realidade" o que significa que "o econômico e o extra econômico convertem-se continuamente um no outro, estão numa irrevogável relação recíproca" onde a relação ente ser e consciência assume, ao contrário, "aquela orgânica unidade do ser social, na qual cabe às leis rígidas da economia precisamente e apenas o papel de momento predominante" (LUKÁCS, 2012, p. 101 $310)$.

Essa inter-relação mútua em que o econômico e o extra econômico se convertem um no outro, expressa o próprio fundamento das categorias como formas de ser da própria realidade concreta, da qual Marx se vale, para apreender a legalidade imanente da lógica do funcionamento do modo de produção capitalista. Assim, entendemos que a dialética em Marx é expressa a constatação da objetividade ontológica do ser social; suas relações reais, objetivas e historicamente determinadas pelo desenvolvimento de suas forças materiais, em última instância.

Uma das conquistas mais significativas da dialética marxista radica, exatamente, na referência à unidade contraditória do movimento do capital; concebido em sua articulação com

\begin{tabular}{|l|l|l|l|l|}
\hline Q & Ano 10 & n. 21 & Janeiro - Abril 2021 & p. $340-369$ \\
\hline
\end{tabular}


a totalidade das relações sociais; num nível bastante elevado da mediação dos fenômenos entre si e com o todo concretamente estruturado. Como afirma Leo Kofler, Marx “[...] na análise da mercadoria, a que retorna muitas vezes em sua investigação [...], mostra o modo pelo qual, a partir da análise da relação entre a parte e o todo, a riqueza concreta das contradições dialéticas se desenvolve crescentemente no interior de um processo unitário, descobrindo-se assim a essência das manifestações". A essência objetiva do real é desvelada por meio do processo do abstrato ao concreto; da "concreção real"; das aproximações sucessivas visando demonstrar "que a mercadoria é apenas a expressão reificada de um processo social vivo e complexo, uma célula na qual se reflete o todo, é uma das melhores conquistas da dialética marxista" (KOFLER, 2010, p. 61).

O rigor metodológico marxiano busca apreender o movimento da realidade em sua própria totalidade histórica; em sua legalidade específica e explicitar a essência das coisas do mundo em suas determinações objetivas. Pois, como assinala Lukács "sendo a objetividade uma prioridade ontológica primária de todo ente, é nela que reside a constatação de que o ente originário é sempre uma totalidade dinâmica, uma unidade de complexidade e processualidade" (LUKÀCS, 2012, p. 304). A perspectiva da ontologia do ser social (uma ontologia materialista) trata então, de compreender o "ser-precisamente-assim" de um conjunto fenomênico complexo em interconexão com as legalidades gerais que o determinam. Nesse sentido, o espelhamento dialético do real por parte do indivíduo pesquisador no plano do pensamento é, portanto, possibilitado pelas categorias ontológicas.

Assim, com base no filósofo Eduardo Chagas (2012, p. 2-3): “[...], pode-se dizer que o método dialético de Marx, pressupõe, sim, dois momentos inseparáveis: a investigação (ou a pesquisa) e a exposição (ou a apresentação)". E de forma mais precisa ainda afirma o autor que:

A investigação, ou o método de investigação (Forschungsmethode), é o esforço prévio de apropriação, pelo pensamento, das determinações do conteúdo do objeto no próprio objeto, quer dizer, uma apropriação analítica, reflexiva, do objeto pesquisado antes de sua exposição metódica. E a exposição, ou o método de exposição (Darstellungsmethode), não é simplesmente uma auto exposição do objeto, senão ele seria acrítico, mas é uma exposição crítica do objeto com base em suas contradições, quer dizer, uma exposição crítico-objetiva da lógica interna do objeto, do movimento efetivo do próprio conteúdo do objeto (CHAGAS, 2012, p. 3, itálico nosso).

O conhecimento científico, para a dialética marxiana, só é possível porque existem legalidades, regularidades que dirigem a realidade e que os sujeitos, por meio de seus atos teleológicos, produzem a realidade social e a reproduzem, no plano da ideia (por meio das

\begin{tabular}{|l|l|l|l|l|}
\hline Qenista Dialectus & Ano 10 & n. 21 & Janeiro - Abril 2021 & p. $340-369$ \\
\hline
\end{tabular}


categorias ontológicas do real), o movimento efetivo da totalidade concreta em sua dinâmica contraditória. Portanto, conhecer a essência do real é apreender a sua dinâmica e estrutura tal como ele é em si mesmo.

Continuando o debate com Löwy e Naïr, estes autores ainda afirmam que a obra mais importante do período imediatamente posterior a Primeira Guerra Mundial e, que representa o mais elevado nível da dialética marxista,

[...] é, sem dúvida, [...] História e consciência de classe, de 1923. Amigo de Laks, discípulo de Marx Weber, formado na escola neokantiana de Heidelberg, Georg Lukács torna-se marxista após a revolução de 1917 e escreve esse livro, que constitui uma verdadeira enciclopédia das ciências sociais e da filosofia marxistas. O próprio título da obra resume a tese central da dialética lukacsiana: a identidade entre o sujeito (a consciência de classe) e o objeto (a história). Quando o proletariado pensa a sociedade capitalista, toma, com isso, consciência de si e orienta-se para a revolução; assim, a análise marxista do capitalismo é ao mesmo tempo ciência do objeto e consciência do sujeito (LÖWY e NAÏR, 2008, p. 92, itálico no original).

De igual modo, no âmbito da realidade prática, uma vez que os homens constroem a história e transformam a sociedade, eles também transformam a si mesmo e a sua própria consciência. (Apesar de Godmann, segundo Löwy e Naïr, conssiderar que Lukács incorre no equívoco idealista de influência hegeliana ao assinalar que essa identidade é "total"). Portanto, eles (os homens) ao mesmo tempo se constituem enquanto sujeito e objeto da sua própria ação social, diz Goldmann (Kierkerkaard vivant, 1964).

Sendo assim, (LÖWY e NAÏR, 2008, p. 92-93, aspas no original) apontam que, para

Lukács,

[...] o proletariado revolucionário, sujeito-objeto da história, tende a se identificar com a humanidade e a suprimir as classes; ele se acha, por consequência, numa situação ímpar em relação a todas as classes revolucionárias que o precederam, porque é a única classe que pode fazer uma revolução não para garantir certos privilégios, mas para se abolir enquanto classe e abolir ao mesmo tempo qualquer privilégio de classe. O proletariado é, portanto, uma força revolucionária "interna”, constitutiva do próprio objeto que quer transformar (a sociedade burguesa): é a partir dessa premissa política fundamental que Lukács vai recusar ao mesmo tempo o moralismo neokantiano dos revisionistas e o reformismo mecanicista do centro "ortodoxo".

Nesse contexto histórico, a "verdade universal" é a consciência atribuída do proletariado revolucionário, ou seja, a consciência que reconhece seus limites e que corresponde aos interesses históricos e à sua condição concreta de classe. É nesse sentido, que Löwy e Naïr (2008, p. 93, itálico no original) afirmam: Lucien Goldmann "fez dos quatro conceitos-chave de História e consciência de classe - a identidade sujeito-objeto, a consciência possível, a reificação e a totalidade - o ponto de partida metodológico de toda a sua obra”.

\begin{tabular}{|l|l|l|l|l|}
\hline Qevista 2 Dialectus & Ano 10 & n. 21 & Janeiro - Abril 2021 & p. 340 - 369 \\
\hline
\end{tabular}


Pensadores como Herbert Marcuse também tentaram (uma fundamentação teóricometodológica da categoria da totalidade), defender que a perspectiva da totalidade no marxismo tem características autênticas, de origens hegelianas, mas que se distingue destas por outros fundamentos.

Esse problema levantado pelo filósofo marxista alemão Herbert Marcuse em seu livro Razão e revolução, publicado originalmente em 1941, lança luz sobre os fundamentos teórico-metodológicos da categoria a totalidade no marxismo, e que nos permite estabelecer com Lukács uma reflexão importante. Tanto para Marx como para Hegel, a verdade está na totalidade negativa, afirma Marcuse, convém, todavia, demarcar suas diferenças.

Nesse sentido, enfatiza o filósofo frankfurtiano:

[...] a totalidade na qual a teoria marxista se move é diferente da totalidade da filosofia de Hegel, e esta diferença assinala a diferença decisiva entre as dialéticas de Hegel e Marx. Para Hegel, a totalidade era a totalidade da razão, um sistema ontológico fechado, que acabava por se identificar com o sistema racional da história. O processo dialético de Hegel era, pois, um processo ontológico universal no qual a história se modelava sobre o processo metafísico do ser. Marx, ao contrário, desliga a dialética desta base ontológica. Na sua obra, a negatividade da realidade torna-se uma condição histórica que não pode ser hipostasiada como uma condição metafísica (MARCUSE, 2004, p. 269-270).

A negatividade acaba se tornando uma condição social, correspondente a uma forma histórica específica da sociedade. A totalidade que a dialética marxista alcança, portanto, de acordo com Marcuse, é a totalidade da sociedade de classes, e a negatividade que vige sob as contradições desta dialética e que confere forma ao seu conteúdo enquanto um todo é a “negatividade das relações de classe". No mundo social tal negatividade conduz às contradições da sociedade de classes e, dessa maneira, continua sendo a força motriz do "progresso social". Sendo assim, o método dialético marxista, "por sua própria natureza, torna-se método histórico [...] A dialética toma os fatos como elementos de uma totalidade histórica definida da qual elas não podem se isolar" (MARCUSE, 2004, p. 270).

Esse fundamento do método dialético, pressupõe que todo fato só tem condição de ser submetido à análise história ao passo que cada fato é motivado pelos antagonismos do processo histórico-social. Pois, o aspecto histórico da dialética marxista engloba a negatividade existente e sua negação. O estado de uma determinada coisa que é negativo somente se torna positivo em face da "libertação das possibilidades" intrínsecas a ele, isto porque, afirma Marcuse (2004, p. 270) “a negação da negação, se realiza pelo estabelecimento de uma nova ordem de coisas. A negatividade e sua negação são duas fases diferentes do mesmo processo histórico", vinculadas pela ação histórica dos homens em seu contexto social específico.

\begin{tabular}{|l|l|l|l|l|}
\hline Qenista Dialectus & Ano 10 & n. 21 & Janeiro - Abril 2021 & p. 340 - 369 \\
\hline
\end{tabular}


Com efeito, esse "novo estado é a verdade do velho",

[...] mas esta verdade não cresce firme e automaticamente a partir do estado mais antigo; ela só pode ser libertada por uma ação autônoma dos homens, ação que anulará a totalidade do estado negativo existente. A verdade, resumindo, nem constitui uma esfera separada da realidade histórica, nem uma região de ideias eternamente válidas. É fato que ela transcende a realidade histórica dada, mas somente na medida em que passa de um estágio histórico a outro. O estado negativo, bem como sua negação, é um acontecimento concreto dentro da mesma totalidade (MARCUSE, 2004, p. 270271).

A dialética marxista, diz Marcuse, ainda constitui um método histórico em outro sentido, ou seja, ela se ocupa com uma etapa "particular" do processo histórico-social. É nesse sentido, que Marx critica a dialética hegeliana porque esta, de um modo geral, generaliza "o movimento dialético em um movimento de todo o ser", do ser enquanto tal, "atingindo com isto apenas a "expressão abstrata, lógica, especulativa do movimento da história" (MARCUSE apud, MARX, 2004, p. 271). A dialética hegeliana "produz uma forma lógico-abstrata" do processo de desenvolvimento histórico, enquanto a dialética marxista, do contrário, é a própria expressão do movimento "concreto real". Portanto, a negatividade com que inicia a dialética marxista, é aquela que caracteriza a condição da existência humana no contexto da sociedade de classes, onde os antagonismos que potencializam esta negatividade, e que por fim a aniquilam, são os conflitos da sociedade de classes.

Pensar a totalidade, enquanto um princípio constitutivo do método dialético de Marx é, também, fazer alusão à ideia de que a totalidade tem um fundamento filosófico. Nesse sentido, para o filósofo e sociólogo marxista francês Henri Lefebvre a noção de totalidade é uma noção filosófica, pois, "não há um filósofo digno deste nome que não tenha contribuído para elaborá-la. Não há um filósofo digno deste nome que não tenha se esforçado para alcançar uma representação do universo como uma totalidade"16 (LEFEBVRE, 2011, p. 105, tradução nossa).

De acordo com Lefebvre:

Note-se aqui, desde o princípio deste estudo, uma distinção fundamental. A noção de totalidade pode ser compreendida de duas maneiras opostas: como totalidade fechada e estática - como totalidade aberta e mutável. Quando se quer aplicar a realidades concretas, particularmente as realidades humanas e sociais, esta noção, as modalidades de sua aplicação diferem profundamente segundo a interpretação de tal conceito. Uma totalidade fechada exclui outras totalidades, ou se considera apenas uma em prejuízo das outras, ou as totalidades consideradas permanecem exteriores com respeito as outras. Do contrário, uma totalidade "aberta" pode envolver outras

16 No original: No hay un filósofo digno de este nombre que no haya contribuido a elaborarla. No hay un filósofo digno de este nombre que no se haya esforzado en alcanzar una representación del Universo como totalidad [...] (LEFEBVRE, 2011, p. 105).

\begin{tabular}{|l|l|l|l|l|}
\hline Q Rovista Dialectus & Ano 10 & n. 21 & Janeiro - Abril 2021 & p. 340 - 369 \\
\hline
\end{tabular}


totalidades igualmente abertas, podendo-se implicar em profundidade, etc. A noção de totalidade aberta é além disso mas sutil, mas difícil de vincular-se aquela, mas simples, denominada totalidade fechada, se apresentam como sistemas. A noção de totalidade aberta corresponde outro tipo de investigação e de pensamentos filosóficos ${ }^{17}$ (LEFEBVRE, 2001, p. 105, tradução nossa, aspas e itálico no original).

Essa perspectiva teórica desenvolvida por Lefebvre que considera a totalidade a partir de duas maneiras opostas quando aplicadas a realidade, em especial a realidade humana e social, diferem entre si conforme a aplicação de suas noções. Fechada, porque ela exclui a interação com as outras totalidades, uma vez que se considera apenas uma delas em prejuízo das outras, ou seja, não se leva em conta a relação de reciprocidade entre as totalidades inerentes em si. E a totalidade $a b e r t a$, porque ela configura uma noção de totalidade fundada na interação dialética das partes e o todo, e das totalidades entre si. Assim, a noção de totalidade nas ciências sociais, foi desenvolvida lentamente, de uma maneira específica, mas, confusa, tal como a noção de totalidade nas outras ciências. Pois, a representação confusa e intuitiva da natureza e da matéria como um todo, corresponde em primeiro lugar, a noção não menos confusa da sociedade enquanto um todo. Contudo, a noção de totalidade foi se desenvolvendo de forma mais adequada. Desse modo, os teóricos e especialistas em ciências sociais conseguiram encontrar por conta própria a noção de totalidade, na medida em que não se limitam a descrição pura e simples dos fatos isolados.

Sem dúvida, afirma Lefebvre, a noção de totalidade é no fundo, uma noção filosófica. Nesse sentido, para auferir uma conclusão razoável desta noção é, necessário, fazer um exame prudente e rigoroso. Pois assim, podemos ter uma confluência, entre a filosofia e as ciências sociais, como todos sabem, tem uma importância considerável. Para Lefebvre é importante destacar que:

Desde a aurora da filosofia, a noção de totalidade (unidade e multiplicidade indissoluvelmente ligadas, constituem um conjunto ou um todo) aparece como essencial. Os filósofos gregos já propunham ingenuamente, no sentido de uma objetividade imediata, dada, facilmente aceitável. A natureza, para eles, continha algumas características contraditórias: unidade y multiplicidade, mobilidade e

17 No original: Señalemos aquí, desde el principio de este estudio, una distinción fundamental. La noción de Totalidad se puede comprender de dos maneras opuestas: como totalidad cerrada y estática -como totalidad abierta y cambiante. Cuando se quiere aplicar a realidades concretas, particularmente a las realidades humanas y sociales, esta noción, las modalidades de su aplicación difieren profundamente según la interpretación de tal concepto. Una totalidad cerrada excluye otras totalidades, o bien se considera solo una en perjuicio de las otras, o bien las totalidades consideradas permanecen exteriores con respecto a las otras. Por el contrario, uma totalidad 'abierta' puede envolver otras totalidades igualmente abiertas, pudiéndose implicarse a profundidad, etc... La noción de totalidad abierta es además más sutil, más difícil de asir que aquella, más simple, denominada totalidad cerrada, se presentan como unos sistemas. La noción de totalidad abierta corresponde a otro tipo de investigación y de pensamiento filosóficos (LEFEBVRE, 2011, p. 105, itálico no original).

\begin{tabular}{|c|c|c|c|c|}
\hline Qenista Dialectus & Ano 10 & n. 21 & Janeiro - Abril 2021 & p. $340-369$ \\
\hline
\end{tabular}


profundidade, interações superficiais e leis ${ }^{18}$ (LEFEBVRE, 2011, p. 106, tradução nossa).

Essa noção filosófica da totalidade também é histórica como podemos perceber. Pois ela vai ganhado novas configurações teóricas ao longo do tempo, com os avanços das pesquisas. Não temos aqui a pretensão de desenvolver uma reflexão prolongada da noção filosófica da totalidade, mas, situar brevemente seus fundamentos básicos. Desse modo, em Heráclito e seu realismo ingênuo, a totalidade é concebida como uma objetividade dada e imediata, já para Descartes a totalidade se apresenta em sentido abstrato, sendo o homem um todo na totalidade do universo. Mas de uma maneira geral, foram os pensadores-literatos, alguns escritores (como Diderot e Goethe) que em primeiro lugar que compreenderam o homem o humano como totalidade, diz Lefebvre. Já Feuerbach, seguramente, foi quem concebeu o homem mais como uma totalidade da natureza do que uma totalidade ética e social. Todos os homens existem enquanto totalidade, em cada um de nós naturalmente. Enquanto um ser material, ele existe como expressão de seus sentidos, do sexo, do cérebro e do pensamento. $\mathrm{O}$ estudo antropológico do homem foi um esforço de Feuerbach para entender a sociedade como um todo. Todavia, foi Hegel o primeiro a conferir a mais alta dignidade filosófica a noção de totalidade.

Assim, de acordo com Lefebvre, Hegel conseguiu:

[...] com esmero, analisar, examinando em si mesma, elaborado em sua lógica. Ela se encontra ademais em todas as partes do hegelianismo. Ela atravessa, anima o "sistema", esforço de gigante por capturar a Totalidade do universo, da história, do homem. O hegelianismo no conjunto, a Fenomenologia, a Lógica, a história são totalidades parciais, abertas sobre o todo. A noção de totalidade se encontra aqui com uma contradição interna posta em evidência pelos marxistas: as vezes noção aberta, mutável, dialética - as vezes noção fechada, sistemática, metafisicamente imposta de fora e separada do conteúdo vivo do pensamento hegeliano. Assim a contradição interna dessa noção, inerente a ela mesma no curso da história da filosofia, estava no hegelianismo ${ }^{19}$ [...] (LEFEBVRE, 2011, p. 109, tradução nossa, aspas no original).

18 No original: Desde la aurora de la filosofía, la noción de Totalidad (unidad y multiplicidad indisolublemente ligadas, constituyendo un conjunto o un todo) aparece como esencial. Los filósofos griegos la planteaban ingenuamente, en el sentido de una objetividad inmediata, dada, fácilmente asible. La naturaleza, para ellos, contenía algunas características contradictorias: unidad y multiplicidad, movilidad y profundidad, cambios superficiales y leyes (LEFEBVRE, 2011, p. 106).

19 No original: [...] con esmero, analizado, examinado en sí misma, elaborado en su Lógica. Ella se encuentra además en todas partes en el hegelianismo. Ella atraviesa, anima el "sistema", esfuerzo de gigante por asir la Totalidad del universo, de la historia, del hombre. En el hegelianismo en conjunto, la Fenomenología, la Lógica, la historia son totalidades parciales, abiertas sobre el todo. La noción de Totalidad se reencuentra aquí con la contradicción interna puesta em evidencia por los marxistas: a veces noción abierta, cambiante, dialéctica - a veces noción cerrada, sistémica, metafísicamente impuesta desde afuera y separada del contenido viviente del pensamiento hegeliano. ¡Así la contradicción interna de la noción, inherente a ella misma en el curso de la historia de la filosofía, estalla en el hegelianismo [...] (LEFEBVRE, 2011, p. 106).

\begin{tabular}{|c|c|c|c|c|}
\hline Qovista Dialectus & Ano 10 & n. 21 & Janeiro - Abril 2021 & p. $340-369$ \\
\hline
\end{tabular}


Como podemos depreender dessa passagem de Lefebvre, a noção de totalidade perpassa toda a obra de Hegel, pois, ele concebe o homem como uma totalidade da história em todas as suas manifestações. Contudo, a leitura crítica do marxismo sobre o pensamento de Hegel, hauriu uma interpretação que entende a noção de totalidade neste filósofo como uma totalidade às vezes aberta, dinâmica e dialética e às vezes fechada, sistemática e metafísica imposta de fora e separada do aspecto vivo do pensamento hegeliano. Mas, de uma maneira geral, entendemos que a categoria da totalidade em Hegel constitui uma expressão do pensar, ou seja, ela é resultado da especulação pura, do movimento do pensamento que se projeta sobre a realidade. Nesse sentido, a noção de totalidade em Marx tem características radicalmente diferentes em relação às noções de totalidade de Hegel e Feuerbach.

Segundo Lefebvre, em Marx, a noção de totalidade já aparece nas obras de juventude de uma maneira original,

[...] na noção de homem total que ele toma de Feuerbach, mas aprofundada e transformada. O indivíduo é social, sem que tenha o direito de fixá-lo, pelo pensamento, a sociedade em uma abstração exterior a ele. Nem na natureza e na vida biológica, nem na vida da espécie humana e sua história, nem na vida individual e na social, não podem separar-se. O homem é totalidade. Pois suas necessidades e seus órgãos $[\ldots]$ por seu trabalho [...] "O homem se apropria de seu ser universal de maneira universal, pois é tanto homem total” "20 (LEFEBVRE apud MARX, 2011, p. 114, tradução nossa, itálico e aspas no original).

Esta noção de "homem total" em Marx é radicalmente diferente daquela exposta por Feuerbach baseada em seu "princípio antropológico". Pois Marx não concebe o homem como um fato, um todo já dado, como uma realidade meramente natural. Do contrário, ele o considera como um ser historicamente determinado, situado pelas contradições de sua realidade social e suas relações concretas. O problema central destacado por Lefebvre em sua análise sobre a totalidade é a diferença fundamental entre a perspectiva da totalidade fechada e a totalidade aberta. Esta seria, portanto, a diferença metodológica decisiva entre Hegel e Marx, respectivamente, no que diz respeito, a questão da totalidade.

Sobre Lukács e sua perspectiva da totalidade em História e consciência de classe, explica Lefebvre que:

20 No original: [...] en la noción de homem total que él toma de Feuerbach, pero profundizada y transformada. El individuo es social, sin que se tenga el derecho de fijarlo, por el pensamiento, a la Sociedad en una abstracción exterior a él. Ni la naturaleza y la vida biológica, ni la vida de la especie humana y su historia, ni la vida individual y la vida social, no pueden separarse. El hombre es totalidad. Por sus necesidades y sus órganos, [...], por su trabajo [...] "El hombre se apropia de su ser universal de manera universal, pues en tanto hombre total" (LEFEBVRE apud MARX, 2011, p. 114, aspas do original).

\begin{tabular}{|c|c|c|c|c|}
\hline Rovita Dialectus & Ano 10 & n. 21 & Janeiro - Abril 2021 & p. $340-369$ \\
\hline
\end{tabular}


Em sua obra, História e consciência de classe, Georges Lukács a assume como noção central. Mas faz um uso abusivo dela. Não distinguiu claramente a totalidade fechada (abstrata, imóvel) da totalidade mutável, aberta. E sobretudo ele aplicou a noção de totalidade fechada a "consciência de classe" do proletariado [...] $]^{21}$ (LEFEBVRE, 2011, p. 117, itálico e aspas no original).

De acordo com Lefebvre, em História e consciência de classe, a noção de totalidade aparece como uma noção fechada, abstrata e imóvel. Essa afirmação de Lefebvre, entretanto, não leva em conta que no livro de 1923 Lukács concebe a categoria da totalidade sob um duplo aspecto determinativo teórico-metodológico, no sentido de que ela possibilita ao proletariado sujeito-objeto idêntico da realidade histórica compreender de forma lógico-ontológica e abstrato-concreta as determinações do mundo objetivo da sociedade capitalista como um todo idealmente articulado (no sentido hegeliano) a partir de sua consciência cognoscente que se interpõe na realidade como um "pensador coletivo". Portanto, em História e consciência de classe Lukács parte inicialmente dessa duplicidade metodológica num movimento de passagem progressiva rumo a sua obra derradeira a Ontologia do ser social para conceber agora de forma plenamente ontológica a totalidade enquanto uma determinação do mundo objetivo.

Essa passagem progressiva de Lukács com relação a fundamentação teóricometodológica da categoria da totalidade entre as obras História e consciência de classe e a Ontologia do ser social tem seu momento decisivo de avanço na leitura do próprio dos originais dos Manuscritos econômico-filosóficos de 1844 de Marx no início da década de 1930 no Instituto Marx-Engels de Moscou onde desenvolveu em parceria com seu amigo de pesquisas Mikhail Lifschitz os elementos teóricos necessários para o aprofundamento da dialética marxista em termos de uma ontologia-materialista. Isso lhe permitiu se apropriar dos fundamentos ontológicos da existência do ser social e, por conseguinte, ter compreendido que as categorias que regem a vida social são categorias (ontológicas) da própria realidade históricoobjetiva, portanto, determinações da ação concreta dos homens em suas relações reais no mundo. Sendo o trabalho, o momento fundante que possibilita o desenvolvimento históricosocial de todos os complexos propriamente humano-sociais.

\section{Referências}

ALTHUSSER, Louis. Por Marx. Campinas, SP: Unicamp, 2015.

21 No original: En su obra, Histoire et consciente de classe, Georges Lukács la asume como noción central. Pero hace un uso abusivo de ella. No ha distinguido claramente la totalidad cerrada (abstraída, inmóvil) de la totalidad cambiante, abierta. Y sobretodo ha aplicado la noción de totalidad cerrada a la "conciencia de classe" del proletariado [...] (LEFEBVRE, 2011, p. 117, tradução nossa, itálico no original e aspas do original).

\begin{tabular}{|l|l|l|l|l|}
\hline Qevista Dialectus & Ano 10 & n. 21 & Janeiro - Abril 2021 & p. 340 - 369 \\
\hline
\end{tabular}


CHAGAS, Eduardo F. O método dialético de Marx: investigação e exposição crítica do objeto.

Síntese Revista de Filosofia, [S.1.], v.38, n.120, 2011. Disponível em: $<$ https://efchagasufc.files.wordpress.com/2012/04/texto-completo-8.pdf $>$. Acesso em: 7 mar. 2018

FREDERICO, Celso. A arte no mundo dos homens: o itinerário de Lukács. São Paulo: Expressão Popular, 2013.

GOLDMANN, Lucien. Marxisme et sciences humanines. São Paulo: Gallimard, 1970.

HEGEL, G. W. F. Enciclopédia das ciências filosóficas: em compêndio (1830). v.I: a ciência da lógica. São Paulo: Loyola, 2012.

LEFEBVRE, Henri. La noción de totalidad em las ciencias sociales. Revista Telos, Universidade Rafael Belloso Chacín, Maracaibo, Venezuela, v.13, n.1, enero/abr. 2011.

LÖWY, Michel e NAÏR, Samir. Lucien Goldmann ou a dialética da totalidade. São Paulo: Boitempo, 2008a.

LUKÁCS, G. História e consciência de classe: estudos sobre a dialética marxista. São Paulo: Martins Fontes, 2003.

. Prolegômenos para uma ontologia do ser social. São Paulo: Boitempo, 2010.

. Para uma ontologia do ser social I. São Paulo: Boitempo, 2012.

. Para uma ontologia do ser social II. São Paulo: Boitempo, 2013.

. El asalto a la razón: La trayectoria del irracionalismo desde Schelling hasta Hittler. México: Fondo de cultura económica, 1959.

. Prólogo. In: Barcelona - México, D. F., 1966, p. 11-31.

Estética: La peculiaridad de lo estético. Ed. Grijalbo,

Estética. v.1. Barcelona: Grijalbo, 1967.

1948.

. Es geht um den Realismus, In:

Essays über Realismus. Berlin: Aufbau,

O romance histórico. São Paulo: Boitempo, 2011.

. Meu caminho para Marx. Notas da Edição Brasileira (publicada originalmente na Revista Nova Escrita/Ensaio especial - Marx Hoje, ano.5, , n.11/12, 1983).

MARCUSE, Herbert. Razão e revolução: Hegel e o advento da teoria social. São Paulo: Paz e Terra, 2004.

MARX, Karl. O Capital: crítica da economia política: Livro I: o processo de produção do capital. São Paulo: Boitempo, 2013.

\begin{tabular}{|l|l|l|l|l|}
\hline Q & Ano 10 & n. 21 & Janeiro - Abril 2021 & p. 340 - 369 \\
\hline
\end{tabular}


Antonio Marcondes dos Santos Pereira / Bruno Alysson Soares Rodrigues/ Eduardo Ferreira Chagas

. Manuscritos econômico-filosóficos. São Paulo: Boitempo, 2010.

. Contribuição à crítica da economia política. São Paulo: Expressão Popular, 2008.

MARX, Karl e ENGELS, Friedrich. A ideologia alemã. São Paulo: Boitempo, 2007.

KOFLER, Leo. História e dialética: estudos sobre a metodologia da dialética marxista. Rio de Janeiro: UFRJ, 2010.

KOSIK, Karel. Dialética do concreto. Rio de Janeiro: Paz e Terra, 2011.

\begin{tabular}{|l|l|l|l|l|}
\hline Q & Ano 10 & n. 21 & Janeiro - Abril 2021 & p. $340-369$ \\
\hline
\end{tabular}

